\title{
Burden of high blood pressure as a contributing factor to stroke in the Japanese community-based diabetic population
}

\author{
Ryosuke Komi ${ }^{1}$ - Fumitaka Tanaka ${ }^{1}$ Shinichi Omama ${ }^{2}$ ' Yasuhiro Ishibashi ${ }^{3} \cdot$ Kozo Tanno $^{4} \cdot$ Toshiyuki Onoda $^{4}$. \\ Masaki Ohsawa ${ }^{1} \cdot$ Kentaro Tanaka $^{1} \cdot$ Akira Okayama $^{5} \cdot$ Motoyuki Nakamura $^{1}$ On behalf of Iwate-Kenco Study Group
}

Received: 19 May 2017 / Revised: 25 October 2017 / Accepted: 27 November 2017 / Published online: 13 April 2018

(c) The Author(s) 2018. This article is published with open access

\begin{abstract}
Diabetes mellitus is characterized by alterations in blood glucose $(\mathrm{BG})$ metabolism, and glycated hemoglobin $\left(\mathrm{Hb}_{1} \mathrm{c}\right)$ has been widely used as a marker of the BG concentration. Diabetes often coexists with high blood pressure (BP). High BP and hyperglycemia are well-known risk factors of stroke. We examined the extent to which the increased risk of stroke in diabetic individuals is attributable to BP and BG using prospectively collected data from the Japanese general population. During an average $8.3 \pm 2.2$ years of follow-up, out 1606 diabetic individuals aged $\geq 40$ years who were free of cardiovascular disease, 119 participants (7.4\%) developed stroke. In multivariable analysis, a significant difference in the risk of incident stroke was noted among the BP categories, including normotension (BP1), prehypertension (BP2), and hypertension $(\mathrm{BP} 3 ; P$ for trend $=0.001)$. By contrast, no difference was noted among the $\mathrm{BG}$ categories, including $\mathrm{HbA}_{1} \mathrm{c}$ levels $<7.0 \%$ (HB1), 7.0-7.9\% (HB2), and $\geq 8.0 \%$ (HB3; $P$ for trend $=0.430$ ). Compared with the category that included both BP1 and HB1, the population-attributable fraction (PAF) for stroke incidence was $52.0 \%$ from the BP2 and BP3 categories and 24.1\% from the HB2 and HB3 categories, and the increased incidence from the HB2 and HB3 categories was mostly caused from coexistent BP2 and BP3 categories. In conclusion, in the Japanese community-based diabetic population, concomitant BP elevation largely contributes to the increased incidence of stroke and links BG elevation, as indicated by $\mathrm{HbA}_{1} \mathrm{c}$, to the increased risk of stroke.
\end{abstract}

\section{Introduction}

The total number of people with diabetes mellitus worldwide is expected to increase from 382 million in 2013 to 592 million in 2035 , and this tendency is projected to be particularly evident among the urban population in developing countries [1]. Furthermore, approximately half of all

Fumitaka Tanaka

ftanaka@iwate-med.ac.jp

1 Department of Internal Medicine, Iwate Medical University, Morioka, Japan

2 Department of Neurosurgery, Iwate Medical University, Morioka, Japan

3 Department of Neurology, Iwate Medical University, Morioka, Japan

4 Department of Hygiene and Preventive Medicine, Iwate Medical University, Morioka, Japan

5 The Research Institute of Strategy for Prevention, Tokyo, Japan individuals with diabetes are undiagnosed and have already developed complications, such as chronic renal disease [2]. Thus, determining how to efficiently intervene all types of diabetes, including unrecognized cases, is important to reduce the risk of atherosclerotic cardiovascular disease (CVD), which is one of the major outcomes of diabetes.

Diabetes is characterized by alterations in blood glucose (BG) metabolism. Hemoglobin $\mathrm{A}_{1} \mathrm{c}\left(\mathrm{HbA}_{1} \mathrm{c}\right)$ is widely used as a marker of average $B G$ concentrations for $\sim 3$ months and exhibits advantages compared with glucose tests [3]. Diabetes is an established risk factor for macro- and microvascular disease [4], but the association of $\mathrm{HbA}_{1} \mathrm{c}$ with macrovascular endpoints, especially stroke, is less stringent than microvascular endpoints in diabetic individuals $[5,6]$. Recent studies suggest the importance of BG fluctuation indicated by hypoglycemia and postprandial glycemic elevation as risk factors of future CVD [7, 8]. However, the $\mathrm{HbA}_{1} \mathrm{c}$ level does not provide a measure of short-term fluctuations of BG and does not necessarily reflect hypoglycemia $[9,10]$. On the other hand, hypertension is a common comorbidity of diabetes [11] and a potent 
predictor of macrovascular disease [12, 13]. In addition, a recent study suggests marked ethnic differences in associations between blood pressure (BP) parameters and stroke and stronger combined effects of hyperglycemia and hypertension in Asians compared with Europeans [14]. Based on these facts, the risk of stroke may be largely attributable to coexisting elevated BP rather than high levels of $\mathrm{HbA}_{1} \mathrm{c}$ in Asian diabetic individuals. Clarifying this hypothesis could lead to a better focus on diabetic populations at high risk for incident stroke, but these studies have not yet been conducted to date.

The objective of the present study was to investigate the extent to which the increased risk of stroke is attributable to $\mathrm{BP}$ and $\mathrm{BG}$ indicated by $\mathrm{HbA}_{1} \mathrm{c}$ in the Japanese communitybased diabetic population.

\section{Methods}

\section{Study participants}

The Iwate-Kenpoku cohort (Iwate-KENCO) study cohort is a population-based prospective study in Japanese residents in three districts (Ninohe, Kuji, and Miyako) of the northern Iwate prefecture, which is located in the northeast of Honsyu, Japan. Details of this cohort are provided elsewhere [15]. Participants were recruited through a governmentregulated health checkup program that was conducted between April 2002 and January 2004. Of these participants, $97 \%$ individuals $(n=26,469)$ agreed to participate in this cohort study. In these individuals, diabetic participants ( $n=1713)$ were selected by one or more of the following criteria: (1) a random BG level $\geq 200 \mathrm{mg} / \mathrm{dl}$ or a fasting BG level $\geq 126 \mathrm{mg} / \mathrm{dl}$, (2) a $\mathrm{HbA}_{1} \mathrm{c}$ (NGSP equivalent value) $\geq 6.5 \%$, and (3) current anti-diabetic therapy. After the exclusion of 107 participants for the following reasons, including age $<40$ years $(n=4)$, missing data at baseline ( $n$ $=6$ ), or prevalent CVD (myocardial infarction or stroke; $n$ $=103$ ), a total of 1606 diabetic participants (763 males and 843 females) were included in the analysis.

\section{Outcome}

The endpoint of the study was newly diagnosed stroke. Diagnosis of stroke was based on the criteria established for the Monitoring System for Cardiovascular Disease commissioned by the Ministry of Health and Welfare [16]. These criteria correspond with those published by the World Health Organization [17], and stroke was defined as the sudden onset of neurological symptoms. Hospitalized patients with incident stroke were registered from April 2002 to August 2007. Patients with transient ischemic attack and traumatic hemorrhagic stroke were excluded from the registration. Registration was initially performed by attending physicians at all the general public hospitals located in the present study area. Furthermore, to ensure the complete capture of all registrations, physicians or trained research nurses visited those hospitals and reviewed the medical charts and/or discharge summaries. Furthermore, to capture the cases that transferred from the study area to other municipalities, we extended the survey to include all teaching hospitals within neighboring municipalities around the study area. The government of Iwate prefecture and the Iwate Medical Association implemented a stroke registration program with other organizations [18]. The study was approved by our institutional ethics committee, and all participants provided written informed consent.

\section{Measurement}

Body mass index (BMI) was calculated by dividing weight (in kilograms) by the square of height (in meters). Participants completed a self-report questionnaire to document their medical history, including current medications and lifestyle factors, such as smoking habits. BP was measured twice using an automatic digital sphygmomanometer after at least 5 minutes of rest in a sitting position, and the average of these two values was used for analysis. Both fasting $(n=374)$ and non-fasting $(n=1232)$ blood samples were drawn from an antecubital vein and collected into vacuum tubes containing a serum separator gel. Tubes were stored immediately after sampling in an icebox and were transported to the laboratory $<8 \mathrm{~h}$ after collection. The estimated glomerular filtration rate (eGFR) was calculated using CKD-EPI equations modified by a Japanese coefficient [19]. $\mathrm{HbA}_{1} \mathrm{c}$ levels were determined by highperformance liquid chromatography using an automated glycohemoglobin analyzer (TOSOH HLC-723G7, Japan) as standardized by the Japan Diabetes Society (JDS). $\mathrm{HbA}_{1} \mathrm{c}$ values were converted to National Glycohemoglobin Standardization Program (NGSP) values, which were calculated with the following formula: $\mathrm{HbA}_{1} \mathrm{c}(\mathrm{NGSP})(\%)=1.02 \times$ $\mathrm{HbA}_{1} \mathrm{c}$ (JDS) $(\%)+0.25(\%)$ [20]. Serum concentrations of low-density lipoprotein cholesterol were measured using an enzymatic homogeneous assay Cholestest-LDL (Daiichi Chemicals Co. Ltd, Tokyo, Japan). Serum concentrations of high-density lipoprotein cholesterol concentrations were measured using an enzymatic method. Dyslipidemia was defined as total cholesterol levels $\geq 240 \mathrm{mg} / \mathrm{dl}$, high-density lipoprotein cholesterol levels $<40 \mathrm{mg} / \mathrm{dl}$, and/or current lipid lowering therapy. Smoking habits were defined based on current smoking behavior. 
Table 1 Baseline characteristics of study participants according to the risk categories of blood pressure and glucose

\begin{tabular}{|c|c|c|c|c|c|c|c|c|}
\hline & \multicolumn{4}{|c|}{ Blood pressure category } & \multicolumn{4}{|c|}{ Blood glucose category } \\
\hline & BP1 & BP2 & BP3 & $P$ value & HB1 & HB2 & HB3 & $P$ value \\
\hline Number & 397 & 580 & 629 & & 876 & 393 & 337 & \\
\hline Sex (men) & $40.8 \%$ & $48.3 \%$ & $51.0 \%$ & 0.005 & $49.2 \%$ & $45.5 \%$ & $45.4 \%$ & 0.331 \\
\hline Age (years) & $\begin{array}{l}64.4 \pm \\
9.7\end{array}$ & $\begin{array}{l}66.0 \pm \\
8.7\end{array}$ & $\begin{array}{l}67.1 \pm \\
8.6\end{array}$ & $<0.001$ & $\begin{array}{l}66.7 \pm \\
8.9\end{array}$ & $\begin{array}{l}66.3 \pm \\
8.6\end{array}$ & $\begin{array}{l}63.9 \pm \\
9.2\end{array}$ & $<0.001$ \\
\hline $\begin{array}{l}\text { Body mass index }(\mathrm{kg} / \\
\left.\mathrm{m}^{2}\right)\end{array}$ & $\begin{array}{l}24.3 \pm \\
3.8\end{array}$ & $\begin{array}{l}25.1 \pm \\
3.5\end{array}$ & $\begin{array}{l}25.6 \pm \\
3.9\end{array}$ & $<0.001$ & $\begin{array}{l}25.0 \pm \\
3.7\end{array}$ & $\begin{array}{l}25.3 \pm \\
3.8\end{array}$ & $\begin{array}{l}25.3 \pm \\
3.9\end{array}$ & $<0.001$ \\
\hline $\begin{array}{l}\text { Systolic blood pressure } \\
(\mathrm{mmHg})\end{array}$ & $\begin{array}{l}109.7 \pm \\
7.2\end{array}$ & $\begin{array}{l}129.5 \pm \\
5.9\end{array}$ & $\begin{array}{l}154.0 \pm \\
13.0\end{array}$ & $<0.001$ & $\begin{array}{l}134.2 \pm \\
20.0\end{array}$ & $\begin{array}{l}133.7 \pm \\
19.5\end{array}$ & $\begin{array}{l}135.0 \pm \\
20.9\end{array}$ & $<0.001$ \\
\hline $\begin{array}{l}\text { Diastolic blood } \\
\text { pressure }(\mathrm{mmHg})\end{array}$ & $\begin{array}{l}66.5 \pm \\
6.6\end{array}$ & $\begin{array}{l}75.2 \pm \\
6.4\end{array}$ & $\begin{array}{l}86.0 \pm \\
9.0\end{array}$ & $<0.001$ & $\begin{array}{l}77.1 \pm \\
10.7\end{array}$ & $\begin{array}{l}76.8 \pm \\
10.8\end{array}$ & $\begin{array}{l}78.4 \pm \\
11.1\end{array}$ & $<0.001$ \\
\hline $\mathrm{HbA}_{1} \mathrm{c}(\mathrm{NGSP}, \%)$ & $\begin{array}{l}7.3 \pm \\
1.6\end{array}$ & $\begin{array}{l}7.2 \pm \\
1.3\end{array}$ & $7.2 \pm 1.4$ & $<0.001$ & $6.3 \pm 0.6$ & $7.4 \pm 0.3$ & $9.3 \pm 1.3$ & $<0.001$ \\
\hline Dyslipidemia & $19.4 \%$ & $14.8 \%$ & $17.2 \%$ & 0.168 & $16.0 \%$ & $14.5 \%$ & $22.0 \%$ & 0.016 \\
\hline $\begin{array}{l}\text { Estimated GFR (ml/ } \\
\left.\mathrm{min} / 1.73 \mathrm{~m}^{2}\right)\end{array}$ & $\begin{array}{l}77.0 \pm \\
11.1\end{array}$ & $\begin{array}{l}74.9 \pm \\
10.9\end{array}$ & $\begin{array}{l}74.7 \pm \\
10.6\end{array}$ & 0.011 & $\begin{array}{l}74.4 \pm \\
10.6\end{array}$ & $\begin{array}{l}74.8 \pm \\
11.4\end{array}$ & $\begin{array}{l}78.6 \pm \\
10.3\end{array}$ & 0.011 \\
\hline Current smoking & $17.6 \%$ & $14.7 \%$ & $15.7 \%$ & 0.455 & $15.6 \%$ & $15.5 \%$ & $16.6 \%$ & 0.901 \\
\hline Medication for diabetes & $45.3 \%$ & $50.2 \%$ & $43.6 \%$ & 0.063 & $40.3 \%$ & $50.6 \%$ & $57.3 \%$ & $<0.001$ \\
\hline $\begin{array}{l}\text { Medication for } \\
\text { hypertension }\end{array}$ & $14.1 \%$ & $22.4 \%$ & $27.2 \%$ & $<0.001$ & $23.2 \%$ & $23.2 \%$ & $18.7 \%$ & 0.214 \\
\hline $\mathrm{HbA}_{1} \mathrm{c}$ category & & & & 0.895 & & & & $<0.001$ \\
\hline$<7.0 \%$ (HB1) & $53.9 \%$ & $54.3 \%$ & $55.2 \%$ & & & & & \\
\hline $7.0-7.9 \%(\mathrm{HB} 2)$ & $26.2 \%$ & $24.3 \%$ & $23.5 \%$ & & & & & \\
\hline$\geq 8.0 \%$ (HB3) & $19.9 \%$ & $21.4 \%$ & $21.3 \%$ & & & & & \\
\hline $\begin{array}{l}\text { Blood pressure } \\
\text { category }^{\mathrm{a}}\end{array}$ & & & & & & & & 0.895 \\
\hline Normotension (BP1) & & & & & $24.4 \%$ & $26.5 \%$ & $23.4 \%$ & \\
\hline Prehypertension (BP2) & & & & & $36.0 \%$ & $35.9 \%$ & $36.8 \%$ & \\
\hline Hypertension (BP3) & & & & & $39.6 \%$ & $37.7 \%$ & $39.8 \%$ & \\
\hline
\end{tabular}

Data are presented as mean \pm standard deviation or percentage. Dyslipidemia was defined as total cholesterol levels $\geq 240 \mathrm{mg} / \mathrm{dl}$, high-density lipoprotein cholesterol levels $<40 \mathrm{mg} / \mathrm{dl}$, and/or current lipid lowering therapy

$B P$ blood pressure, $H B \mathrm{HbA1c}, G F R$ glomerular filtration rate

${ }^{a}$ Blood pressure categories was defined as follows: normotension: systolic BP $120 \mathrm{mmHg}$ and diastolic BP $80 \mathrm{mmHg}$; prehypertension: systolic $\mathrm{BP} \geq 120 \mathrm{mmHg}$ but $140 \mathrm{mmHg}$ or diastolic $\mathrm{BP} \geq 80 \mathrm{mmHg}$ but $90 \mathrm{mmHg}$; hypertension: either systolic BP $\geq 140 \mathrm{mmHg}$ or diastolic $\mathrm{BP} \geq 90$ $\mathrm{mmHg}$

\section{BP and BG classification}

According to baseline BP levels, participants were classified into the following three groups according to the Seventh Report of the Joint National Commission (JNC-7): normotension (BP1) defined as systolic BP $<120 \mathrm{mmHg}$ and diastolic $\mathrm{BP}<80 \mathrm{mmHg}$; prehypertension (BP2) defined as systolic $\mathrm{BP} \geq 120 \mathrm{mmHg}$ but $<140 \mathrm{mmHg}$ or diastolic $\mathrm{BP} \geq$ $80 \mathrm{mmHg}$ but $<90 \mathrm{mmHg}$; hypertension (BP3) defined as either systolic $\mathrm{BP} \geq 140 \mathrm{mmHg}$ or diastolic $\mathrm{BP} \geq 90 \mathrm{mmHg}$ [21]. This classification was also applied to individuals with anti-hypertensive agents use. Further, participants were classified into the following three groups according to baseline $\mathrm{HbA}_{1} \mathrm{c}$ levels: $\mathrm{HbA}_{1} \mathrm{c} ;<7.0 \%$ (HB1), 7.0 to $7.9 \%$
(HB2) and $\geq 8.0 \%$ (HB3). This classification was also applied to individuals treated with anti-diabetic medication.

\section{Statistical analysis}

The baseline data are presented as the mean \pm standard deviation (SD) or percentage. Analysis of covariance and logistic regression with adjustments for CVD risk factors at baseline were conducted to compare means and proportions, respectively, across the $\mathrm{BP}$ and $\mathrm{BG}$ categories. Comparison of continuous variables was performed by one-way analysis of variance. $\chi^{2}$ test was used for comparison of categorical variables.

A multivariable Cox proportional hazards model, including age, sex, BMI, eGFR, dyslipidemia (yes or no), 
Table 2 Hazard ratios for stroke events according to the risk categories of blood pressure and glucose in diabetic population

\begin{tabular}{|c|c|c|c|c|c|c|c|c|c|}
\hline & $\begin{array}{l}\text { No. of } \\
\text { subjects }\end{array}$ & $\begin{array}{l}\text { No. of } \\
\text { events }\end{array}$ & $\begin{array}{l}\text { No./1,000 } \\
\text { person years }\end{array}$ & $\begin{array}{l}\text { Sex and age } \\
\text { adjusted HR } \\
\text { and } 95 \% \mathrm{CI}\end{array}$ & $P$ value & $\begin{array}{l}P \text { for } \\
\text { trend }\end{array}$ & $\begin{array}{l}\text { Multivariable- } \\
\text { adjusted } \mathrm{HR}^{\mathrm{a}} \\
\text { and } 95 \% \mathrm{CI}\end{array}$ & $P$ value & $\begin{array}{l}P \text { for } \\
\text { trend }\end{array}$ \\
\hline $\begin{array}{l}\text { Blood pressure } \\
\text { category }\end{array}$ & & & & & & 0.001 & & & 0.001 \\
\hline Normotension & 397 & 13 & 3.8 & 1.00 & & & 1.00 & & \\
\hline Prehypertension & 580 & 38 & 7.9 & $1.86 \quad 0.99-3.50$ & 0.054 & & $1.85 \quad 0.98-3.50$ & 0.056 & \\
\hline Hypertension & 629 & 68 & 13.4 & $2.94 \quad 1.62-5.34$ & 0.000 & & $2.87 \quad 1.57-5.26$ & 0.001 & \\
\hline $\mathrm{HbA}_{1} \mathrm{c}$ category & & & & & & 0.409 & & & 0.430 \\
\hline$<7.0 \%$ & 876 & 65 & 9.0 & 1.00 & & & 1.00 & & \\
\hline $7.0 \%-7.9 \%$ & 393 & 27 & 8.1 & $0.97 \quad 0.62-1.52$ & 0.884 & & $0.98 \quad 0.63-1.55$ & 0.945 & \\
\hline$\geq 8.0 \%$ & 337 & 27 & 9.8 & $1.33 \quad 0.84-2.09$ & 0.220 & & $1.33 \quad 0.84-2.12$ & 0.224 & \\
\hline
\end{tabular}

$H R$ hazard ratio, $C I$ confidence interval

${ }^{a}$ Hazard ratio in a multivariable Cox proportional hazards model including age, sex, body mass index, estimated glomerular filtration rate, dyslipidemia (yes or no), smoking habits (yes or no), and anti-hypertensive and anti-diabetic medications (yes or no)

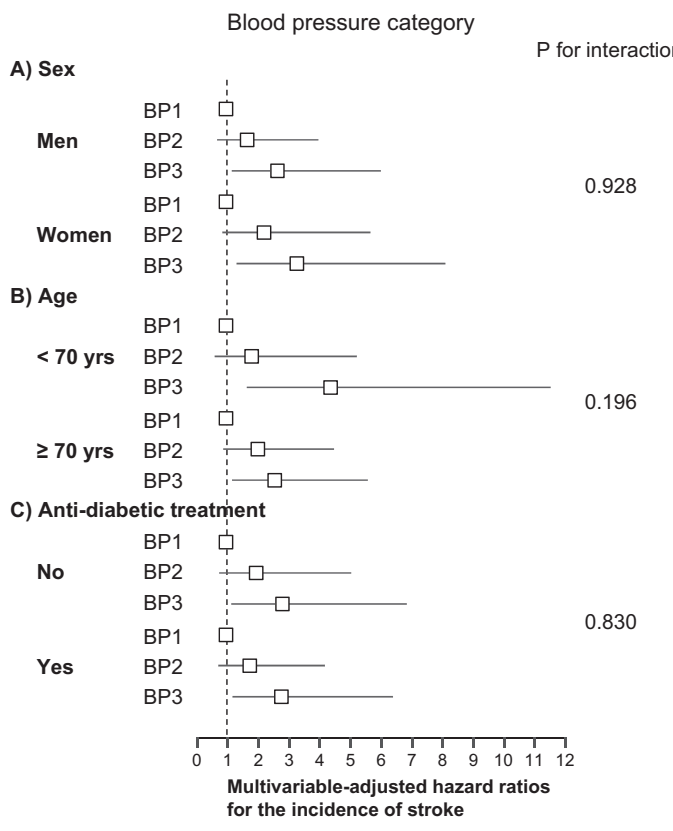

Fig. 1 Multivariable-adjusted hazard ratios for the incidence of stroke according to the categories of sex, age, and status of anti-diabetic medication. BP1: normotension; BP2: prehypertension; BP3:

smoking habits (yes or no), and anti-hypertensive and antidiabetic medications (yes or no), was constructed. A Cox regression analysis was conducted to estimate the effect of the BP and BG categories on the incidence of stroke. This analysis was also conducted separately according to sex, age (above or below 70 years), and status of anti-diabetic medication. The attributable risks for incidence of stroke from the $\mathrm{BP}$ and $\mathrm{BG}$ categories were estimated using a multivariable Cox proportional hazards model. To estimate the attributable risk, the population-attributable fraction (PAF) was calculated as Pe $\times[$ hazard ratio $(\mathrm{HR})-1] / \mathrm{HR}$, in

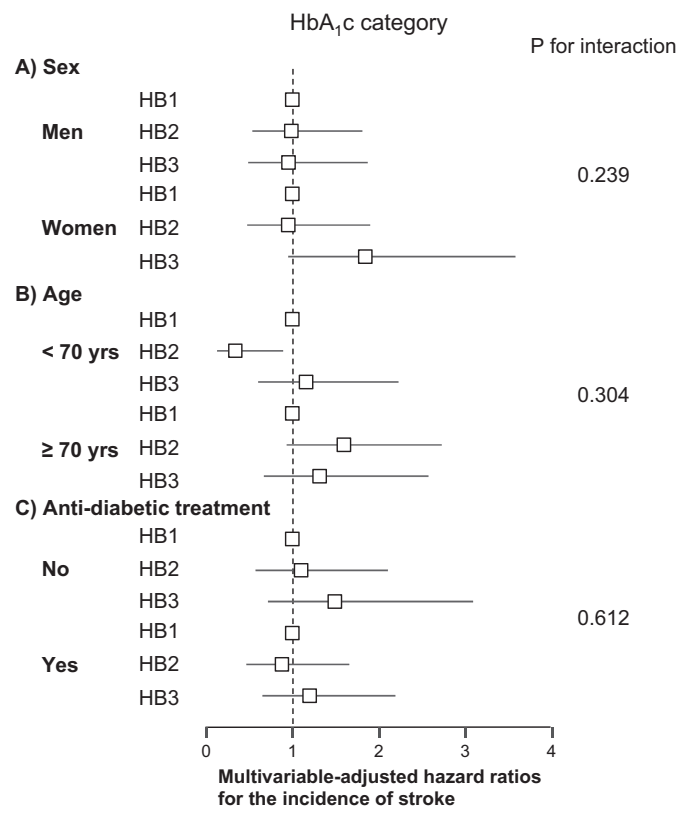

hypertension; $\mathrm{HB} 1: \mathrm{HbA}_{1} \mathrm{c}<7.0 \%$; $\mathrm{HB} 2: \mathrm{HbA}_{1} \mathrm{c}$ from 7.0 to $7.9 \%$; HB3: $\mathrm{HbA}_{1} \mathrm{c} \geq 8.0 \%$

which Pe is the proportion of incident cases in each risk category and HR is the full multiple-adjusted HR. Further, to compare the combined effect of $\mathrm{BP}$ and $\mathrm{HbA}_{1} \mathrm{c}$ categories on incident risk of stroke, the HR and PAF for stroke incidence among the combination category of BP (BP1, $\mathrm{BP} 2$, and $\mathrm{BP} 3)$ and $\mathrm{BG}(\mathrm{HB} 1, \mathrm{HB} 2$, and $\mathrm{HB} 3)$ were computed.

All data were analyzed with SPSS statistical software version 22.0 (IBM Japan, Tokyo, Japan). $P<0.05$ was considered to be statistically significant. 


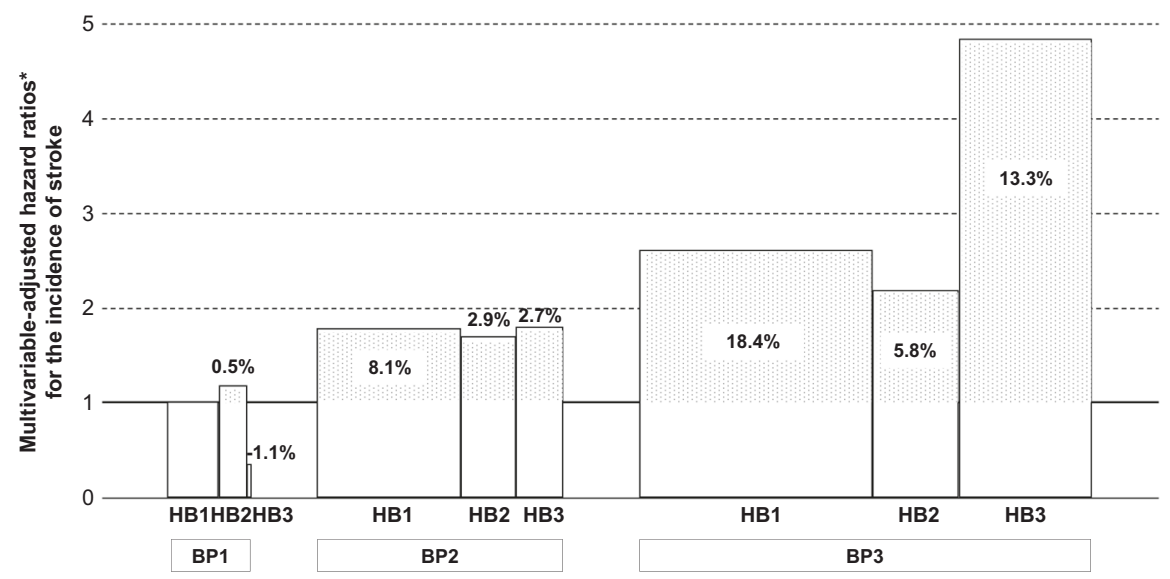

Fig. 2 Multivariable-adjusted hazard ratios and the populationattributable fractions for the incidence of stroke in the combination category of blood pressure and glucose. BP1: normotension; BP2: prehypertension; $\mathrm{BP} 3$ : hypertension; $\mathrm{HB} 1: \mathrm{HbA}_{1} \mathrm{c}<7.0 \%$; $\mathrm{HB} 2$ :
$\mathrm{HbA}_{1} \mathrm{c}$ from 7.0 to $7.9 \%$; $\mathrm{HB} 3: \mathrm{HbA}_{1} \mathrm{c} \geq 8.0 \%$. Dot areas represent the population-attributable fraction for incident stroke from exposure for each risk category at baseline. Hazard ratios were compared with the category with both BP1 and HB1

\section{Results}

The present diabetic cohort consisted of $52.5 \%$ females, $39.8 \%$ elderly participants ( $\geq 70$ years), and $46.4 \%$ participants undergoing treatment with anti-diabetic medication. Table 1 presents the baseline characteristics of study participants according to the BP and BG categories. Participants were likely to exhibit an increased prevalence of elevated BP categories given that $75.3 \%$ of total participants were included in the BP2 or BP3 category. Inversely, the prevalence of participants classified in the HB2 or HB3 category was likely to be lower.

During the average $8.3 \pm 2.2$ years of follow-up, 119 (7.4\%) participants developed stroke, including cerebral infarction $(n=77)$, intracerebral hemorrhage $(n=32)$, subarachnoid hemorrhage $(n=7)$, and cryptogenic stroke $(n=3)$. As shown in Table 2, in a multivariable analysis, a significant difference in the risk of incident stroke was noted among the BP categories $(P$ for trend $=0.001)$. By contrast, no difference was noted among the BG categories $(P$ for trend $=0.430)$. These results were similar to separate analyses based on sex, age, or diabetic medical status (Fig. 1).

Figure 2 presents the HRs and PAFs for stroke incidence in the combination category of $\mathrm{BP}$ (BP1, BP2, and BP3) and BG (HB1, HB2, and HB3). The population-attributable fraction (PAF) for stroke incidence was $44.7 \%$ in total from the BP2 and BP3 categories and $21.0 \%$ in total from the HB2 and HB3 categories compared with the category with both $\mathrm{BP} 1$ and $\mathrm{HB} 1$. In addition, regardless of the BG categories, the increased incidence of stroke was mostly caused by the BP2 and BP 3 categories. By contrast, regardless of the $\mathrm{BG}$ categories, the increased incidence of stroke was mostly caused from the BP2 and BP3 categories, in contrast to being little caused from the BP1 category (Fig. 2).

\section{Discussion}

The key finding in the present study is that in the Japanese community-based diabetic population, approximately half of stroke events were attributed to an increased incidence due to the prehypertensive and hypertensive categories, and this attribution to $\mathrm{BP}$ elevation was more than twice as large as that to $\mathrm{HbA}_{1} \mathrm{c}$ elevation $(\geq 7.0 \%)$. In addition, the increased incidence of stroke from elevated $\mathrm{HbA}_{1} \mathrm{c}$ categories was mostly caused by the coexistence of elevated $\mathrm{BP}$ categories. These results suggest that concomitant BP elevation largely contributes to stroke incidence and links $B G$ elevation indicated by $\mathrm{HbA}_{1} \mathrm{c}$ to the excessive risk of stroke in a diabetic population.

$\mathrm{HbA}_{1} \mathrm{c}$ has been shown to be a predictor for the risk of CVD incidence in prospective studies [22-27]. However, in the Women's Health Study, $\mathrm{HbA}_{1} \mathrm{c}$ did not predict the risk of CVD events independent of traditional CVD risk factors, leading the authors to suggest the involvement of factors other than $\mathrm{HbA}_{1} \mathrm{c}$ might affect CVD risk [28]. Several recent studies have indicated that glycemic variability plays a role in the pathogenesis of atherosclerosis and may be an independent risk factor for cardiovascular complications in diabetic patients [29-31]. In a cohort at risk for diabetes, postchallenge plasma glucose and glycemic spikes were more strongly associated with carotid atherosclerosis than $\mathrm{HbA}_{1} \mathrm{c}$ levels [31]. Further, in populations of Asian origin, 2-hour plasma glucose after a glucose tolerance test was superior to fasting plasma glucose for prediction of CVD mortality [32]. However, the changes in glucose concentration from before to after a meal are poorly correlated with $\mathrm{HbA}_{1} \mathrm{c}$ in contrast to fasting and mean plasma glucose concentrations, which are highly correlated with $\mathrm{HbA}_{1} \mathrm{c}$ [9]. These evidence may account for no significant difference in 
the risk of stroke among the $\mathrm{HbA}_{1} \mathrm{c}$ categories in the present study. In addition, low $\mathrm{HbA}_{1} \mathrm{c}$ levels are associated with the increased risk of cardiac events and mortality among type 2 diabetic patients with BG-lowering treatment [33]. This evidence may also partly explain the lack of an association between $\mathrm{HbA}_{1} \mathrm{c}$ and stroke events among our study participants undergoing anti-diabetic medical treatment.

Previous studies have demonstrated the close relationship between BP and subclinical atherosclerosis or incident stroke in diabetes [12, 13, 34]. In Korean subjects with $\mathrm{HbA}_{1} \mathrm{c} \geq 6.5 \%$, hypertension affected intracranial arterial stenosis to a greater extent than glycemia indicated by $\mathrm{HbA}_{1} \mathrm{c}$ [34]. The Framingham Heart Study reported that compared with normotension, hypertension was associated with a $57 \%$ increase in the risk of stroke events in diabetic individuals [12]. The burden of elevated BP on incident stroke may account for the increased prevalence of the elevated BP category in the diabetic population. Participants in the present study exhibited an increased prevalence of the categories with elevated BP (36 and 39\% in the BP2 and BP3 categories, respectively) in contrast to a reduced prevalence of the categories with higher $\mathrm{HbA}_{1} \mathrm{c}$ levels (24 and $21 \%$ in the HB2 and HB3 categories, respectively; Table 1). These results were consistent with previous reports demonstrating that diabetic individuals were composed of $31 \%$ prehypertensive and $34-58 \%$ hypertensive individuals $[12,35,36]$. The coexistence of diabetes and elevated $\mathrm{BP}$ are partly mediated through the presence of insulin resistance, chronic activation of the renin-angiotensin-aldosterone system, the sympathetic nervous system, and abnormalities associated with innate immunity, inflammation, and oxidative stress [37]. These proatherogenic effects may reflect BP-related risk of stroke.

Previous epidemiological studies have demonstrated the combined effect of prehypertension or hypertension and diabetes on the incidence of CVD [13, 35, 36]. In Framingham participants with diabetes, the increased risk of stroke is more attributable to concomitant hypertension [12]. In observational data from UK Prospective Diabetes Study (UKPDS) participants stratified by $\mathrm{BP}$ and $\mathrm{HbA}_{1} \mathrm{c}$ categories, high $\mathrm{BP}$ (systolic $\mathrm{BP} \geq 150 \mathrm{mmHg}$ ) tended to be associated with a more increased risk of stroke compared with hyperglycemia $\left(\mathrm{HbA}_{1} \mathrm{c} \geq 8.0 \%\right)$ [13]. For the first time, the present study reveals that the excess risk of stroke related to increased BG was mostly attributable to concomitant BP elevation. Our results may partly account for the minimal benefits on stroke incidence due to reductions in BG in recent clinical trials for diabetic individuals [38]. In the post-trial 10-year follow-up for the UKPDS participants, no significant risk reductions in stroke were observed in the intensive BG-lowering group [39]. By contrast, BP reduction confers substantial clinical benefits on stroke incidence. In the observational data from UKPDS participants, tight BP control reduced the risk of stroke to levels comparable to that of microvascular disease [40]. In a randomized clinical trial for type 2 diabetic patients at high risk of CVD, targeting a systolic $\mathrm{BP}$ of less than $120 \mathrm{mmHg}$ compared with less than $140 \mathrm{mmHg}$ reduced $41 \%$ of stroke events, which was a component of the primary outcome [41]. These clinical data are generally consistent with our finding that the removal of coexistent prehypertension and hypertension from diabetes would reduce $45 \%$ of stroke events. In the present subanalysis, the multivariable HR for stroke events in diabetic participants with baseline systolic BP levels $\geq 130 \mathrm{mmHg}$ or diastolic BP levels $\geq 80 \mathrm{mmHg}$ was 1.79 (95\% confidence interval: 1.18 to $2.72, P<0.01$ ), and the PAF from these participants was $32.7 \%$ (data not shown). Therefore, compliance with the current Japanese Society of Hypertension Guidelines of the Management of Hypertension (JSH 2014) [42], which sets $130 / 80 \mathrm{mmHg}$ as a target BP level for diabetic patients, would lead to an approximately one-third reduction in stroke events.

The present study had several limitations. First, Iwate prefecture in which the present study was conducted is an area that is characterized by high salt intake and high incidence rates of stroke [43, 44]. Our diabetic cohort had 9.0 events of stroke per 1000 person-year, which was nearly comparable to those in other diabetic cohorts, such as the Suita cohort (8.9 events per 1000 person-year) $[5,6]$ and the Framingham cohort (11.1 events per 1000 person-year) [12]. However, the dietary habits in our cohort (salt intake: $16.2 \mathrm{~g}$ and $12.8 \mathrm{~g}$ per day in men and women, respectively) [43] might enhance the contribution of BP to the risk of stroke. Second, the present study targets both diabetic individuals with and without ant-diabetic medical treatment who exhibit a difference in diagnosed duration of diabetes and arteriosclerosis progression. The factors that our study could not estimate could influence the relation between BP or BG and the risk of stroke. However, this relation did not differ between our cohorts with and without anti-diabetic medical treatment, suggesting that this limitation would minimally influence our results. Third, the present study set a reference group of $\mathrm{HbA}_{1} \mathrm{c}$ levels of $<7.0 \%$, which was presented as a reasonable $\mathrm{HbA}_{1} \mathrm{c}$ goal by the American Diabetes Association [45]. Baseline $\mathrm{HbA}_{1} \mathrm{c}$ levels in this reference group increased compared with those set in the other studies [5, 13]. However, also when classified into the following four categories, baseline $\mathrm{HbA}_{1} \mathrm{c} ;<6.0 \%$, $6.0-6.9 \%, 7.0-7.9 \%$, and $\geq 8.0 \%, \mathrm{HbA}_{1} \mathrm{c}$ did not stratify the risk of stroke in the present cohort given that the fulladjusted HRs of incident stroke events for $\mathrm{HbA}_{1} \mathrm{c}$ increases were $1.00,1.19,1.15$, and 1.52 , respectively $(P$ for trend $=$ 0.614 , data not shown). Therefore, this limitation would minimally influence the present $\mathrm{HbA}_{1} \mathrm{c}$-related risk of incident stroke. Fourth, the present study did not analyze the association of BP or BG with different stroke types, e.g., 
hemorrhagic stroke, because the cumulative incidence of hemorrhagic stroke was low $[n=36(2.4 \%)]$. In subanalysis, which targeted ischemic stroke as an endpoint, the HR was increased in the prehypertensive and hypertensive categories $[3.03$ (95\% CI, 1.25-7.33), 3.60 (95\% CI, 1.51-8.58), respectively] in contrast to categories with $\mathrm{HbA}_{1} \mathrm{c}$ levels of $7.0-7.9 \%$ and $\geq 8.0 \%$ (data not shown). Fifth, among the present participants, our study did not identify an assortment of the diabetes therapeutic drugs at baseline and the clinical data and prescribed drugs during the follow-up. Therefore, we could not clarify whether this fact influenced our results. Finally, although we extended the survey to the teaching hospitals of several remote municipalities around the study area, it is possible that the identification of some cases that were admitted to medical facilities outside the survey system of the Iwate Stroke Registry was insufficient. Therefore, this insufficiency could lead to an underestimation of our results.

In conclusion, in the Japanese community-based diabetic population, concomitant BP elevation largely contributes to the increased incidence of stroke and links BG elevation indicated by $\mathrm{HbA}_{1} \mathrm{c}$ to the increased stroke risk.

Acknowledgements This research was supported in part by grants-inaid from the scientific research fund of the Ministry of Education, Science, and Culture of Japan (26461082 and 26461083), Tokyo, Japan.

\section{Compliance with ethical standards}

Conflict of interest The authors declare that they have no conflict of interest.

Open Access This article is licensed under a Creative Commons Attribution-NonCommercial-NoDerivatives 4.0 International License, which permits any non-commercial use, sharing, distribution and reproduction in any medium or format, as long as you give appropriate credit to the original author(s) and the source, and provide a link to the Creative Commons license. You do not have permission under this license to share adapted material derived from this article or parts of it. The images or other third party material in this article are included in the article's Creative Commons license, unless indicated otherwise in a credit line to the material. If material is not included in the article's Creative Commons license and your intended use is not permitted by statutory regulation or exceeds the permitted use, you will need to obtain permission directly from the copyright holder. To view a copy of this license, http://creativecommons.org/licenses/by-nc-nd/4.0/.

\section{References}

1. Guariguata L, Whiting DR, Hambleton I, Beagley J, Linnenkamp U, Shaw JE. Global estimates of diabetes prevalence for 2013 and projections for 2035. Diabetes Res Clin Pract. 2014;103:137-49.

2. International Diabetes Federation. IDF Diabetes Atlas. 7th ed. 2015. www.diabetesatlas.org. Accessed on 19 May 2017.

3. American Diabetes Association. Diagnosis and classification of diabetes mellitus. Diabetes Care. 2013;36:S67-74.
4. Emerging Risk Factors Collaboration., Sarwar N, Gao P, Seshasai SR, Gobin R, Kaptoge S, Di Angelantonio E, Ingelsson E, Lawlor DA, Selvin E, Stampfer M, Stehouwer CD, Lewington S, Pennells L, Thompson A, Sattar N, White IR, Ray KK, Danesh J. Diabetes mellitus, fasting blood glucose concentration, and risk of vascular disease: a collaborative meta-analysis of 102 prospective studies. Lancet. 2010;375:2215-22.

5. Stratton IM, Adler AI, Neil HA, Matthews DR, Manley SE, Cull CA, Hadden D, Turner RC, Holman RR. Association of glycaemia with macrovascular and microvascular complications of type 2 diabetes (UKPDS 35): prospective observational study. BMJ. 2000;321:405-12.

6. Khaw KT, Wareham N. Glycated hemoglobin as a marker of cardiovascular risk. Curr Opin Lipidol. 2006;17:637-43.

7. Goto A, Arah OA, Goto M, Terauchi Y, Noda M. Severe hypoglycaemia and cardiovascular disease: systematic review and meta-analysis with bias analysis. BMJ. 2013;347:f4533.

8. Cavalot F, Pagliarino A, Valle M, Di Martino L, Bonomo K, Massucco P, Anfossi G, Trovati M. Postprandial blood glucose predicts cardiovascular events and all-cause mortality in type 2 diabetes in a 14-year follow-up: lessons from the San Luigi Gonzaga Diabetes Study. Diabetes Care. 2011;34:2237-43.

9. American Diabetes Association. Postprandial blood glucose. Diabetes Care. 2001;24:775-8.

10. The Diabetes Control and Complications Trial Research Group. Hypoglycemia in the diabetes control and complications trial. Diabetes. 1997;46:271-86.

11. DeFronzo RA, Ferrannini E. Insulin resistance. A multifaceted syndrome responsible for NIDDM, obesity, hypertension, dyslipidemia, and atherosclerotic cardiovascular disease. Diabetes Care. 1991;14:173-94.

12. Chen G, McAlister FA, Walker RL, Hemmelgarn BR, Campbell NR. Cardiovascular outcomes in framingham participants with diabetes: the importance of blood pressure. Hypertension. 2011;57:891-7.

13. Stratton IM, Cull CA, Adler AI, Matthews DR, Neil HA, Holman RR. Additive effects of glycaemia and blood pressure exposure on risk of complications in type 2 diabetes: a prospective observational study (UKPDS 75). Diabetologia. 2006;49:1761-9.

14. Eastwood SV, Tillin T, Chaturvedi N, Hughes AD. Ethnic differences in associations between blood pressure and stroke in South Asian and European Men. Hypertension. 2015;66:481-8.

15. Nakamura M, Onoda T, Itai K, Ohsawa M, Satou K, Sakai T, Segawa T, Sasaki J, Tonari Y, Hiramori K, Okayama A. Association between serum C-reactive protein levels and microalbuminuria: a population-based cross-sectional study in northern Iwate, Japan. Intern Med. 2004;43:919-25.

16. Study Project of Monitoring System for Cardiovascular Disease commissioned by the Ministry of Health and Welfare. Manual for the registry and follow-up of stroke (in Japanese). Osaka, Japan: National Cardiovascular Center; 1988.

17. World Health Organization MONICA Project. Event registration data component, MONICA manual version 1.1, Document for meeting of MONICA Principal Investigators. Geneva: World Health Organization; 1986.

18. Omama S, Yoshida Y, Ogawa A, Onoda T, Okayama A. Differences in circadian variation of cerebral infarction, intracerebral haemorrhage and subarachnoid haemorrhage by situation at onset. J Neurol Neurosurg Psychiatry. 2006;77:1345-9.

19. Horio M, Imai E, Yasuda Y, Watanabe T, Matsuo S. Modification of the CKD epidemiology collaboration (CKD-EPI) equation for Japanese: accuracy and use for population estimates. Am J Kidney Dis. 2010;56:32-8.

20. The Committee of Japan Diabetes Society on the Diagnostic Criteria of Diabetes Mellitus. Report of the committee on the 
classification and diagnostic criteria of diabetes mellitus. J Jpn Diab Soc. 2010;53:450-67.

21. Chobanian AV, Bakris GL, Black HR, Cushman WC, Green LA, Izzo JL Jr, Jones DW, Materson BJ, Oparil S, Wright JT Jr, Roccella EJ. Joint National Committee on Prevention, Detection, Evaluation, and Treatment of High Blood Pressure. National Heart, Lung, and Blood Institute; National High Blood Pressure Education Program Coordinating Committee. Hypertension. 2003;42:1206-52.

22. Lehto S, Rönnemaa T, Pyörälä K, Laakso M. Predictors of stroke in middle-aged patients with non-insulin-dependent diabetes. Stroke. 1996;27:63-68.

23. Selvin E, Coresh J, Shahar E, Zhang L, Steffes M, Sharrett AR. Glycaemia (haemoglobin A1c) and incident ischaemic stroke: the Atherosclerosis Risk in Communities (ARIC) Study. Lancet Neurol. 2005;4:821-6.

24. Ikeda F, Doi Y, Ninomiya T, Hirakawa Y, Mukai N, Hata J, Shikata K, Yoshida D, Matsumoto T, Kitazono T, Kiyohara Y. Haemoglobin $A 1_{c}$ even within non-diabetic level is a predictor of cardiovascular disease in a general Japanese population: the Hisayama Study. Cardiovasc Diabetol. 2013;12:164.

25. Kuusisto J, Mykkänen L, Pyörälä K, Laakso M. Non-insulindependent diabetes and its metabolic control are important predictors of stroke in elderly subjects. Stroke. 1994;25:1157-64.

26. Moss SE, Klein R, Klein BE, Meuer SM. The association of glycemia and cause-specific mortality in a diabetic population. Arch Intern Med. 1994;154:2473-9.

27. Sunaga K, Miura K, Naruse Y, Sakurai M, Morikawa Y, Kurosawa Y, Nakagawa H. Glycated hemoglobin and risk of stroke, ischemic and hemorrhagic, in Japanese men and women. Cerebrovasc Dis. 2008;26:310-6.

28. Blake GJ, Pradhan AD, Manson JE, Williams GR, Buring J, Ridker PM, Glynn RJ. Hemoglobin A1c level and future cardiovascular events among women. Arch Intern Med. 2004;164:757-61.

29. Monnier L, Mas E, Ginet C, Michel F, Villon L, Cristol JP, Colette C. Activation of oxidative stress by acute glucose fuctuations compared with sustained chronic hyperglycemia in patients with type 2 diabetes. JAMA. 2006;295:1681-7.

30. Hu Y, Liu W, Huang R, Zhang X. Postchallenge plasma glucose excursions, carotid intima-media thickness, and risk factors for atherosclerosis in Chinese population with type 2 diabetes. Atherosclerosis. 2010;210:302-6.

31. Temelkova-Kurktschiev TS, Koehler C, Henkel E, Leonhardt W, Fuecker K, Hanefeld M. Postchallenge plasma glucose and glycemic spikes are more strongly associated with atherosclerosis than fasting glucose or HbAlc level. Diabetes Care. 2000;23:1830-4.

32. Nakagami T, DECODA Study Group. Hyperglycaemia and mortality from all causes and from cardiovascular disease in five populations of Asian origin. Diabetologia. 2004;47:385-94.

33. Currie CJ, Peters JR, Tynan A, Evans M, Heine RJ, Bracco OL, Zagar T, Poole CD. Survival as a function of $\mathrm{HbA}(1 \mathrm{c})$ in people with type 2 diabetes: a retrospective cohort study. Lancet. 2010;375:481-9.
34. Oh HG, Rhee EJ. Blood pressure is the determinant for the increased risk for intracranial arterial stenosis in subjects with elevated glycated hemoglobin levels: The Kangbuk Samsung Health Study. J Stroke Cerebrovasc Dis. 2016;25:2729-34.

35. Kokubo Y, Okamura T, Watanabe M, Higashiyama A, Ono Y, Miyamoto Y, Furukawa Y, Kamide K, Kawanishi K, Okayama A, Yoshimasa Y. The combined impact of blood pressure category and glucose abnormality on the incidence of cardiovascular diseases in a Japanese urban cohort: the Suita Study. Hypertens Res. 2010;33:1238-43.

36. Iso $\mathrm{H}$, Imano $\mathrm{H}$, Kitamura $\mathrm{A}$, Sato $\mathrm{S}$, Naito $\mathrm{Y}$, Tanigawa $\mathrm{T}$, Ohira T, Yamagishi K, Iida M, Shimamoto T. Type 2 diabetes and risk of non-embolic ischaemic stroke in Japanese men and women. Diabetologia. 2004;47:2137-44.

37. Sowers JR. Diabetes mellitus and vascular disease. Hypertension. 2013;61:943-7.

38. Control Group, Turnbull FM, Abraira C, Anderson RJ, Byington RP, Chalmers JP, Duckworth WC, Evans GW, Gerstein HC, Holman RR, Moritz TE, Neal BC, Ninomiya T, Patel AA, Paul SK, Travert F, Woodward M. Intensive glucose control and macrovascular outcomes in type 2 diabetes. Diabetologia. 2009;52:2288-98

39. Holman RR, Paul SK, Bethel MA, Matthews DR, Neil HA. 10year follow-up of intensive glucose control in type 2 diabetes. $\mathrm{N}$ Engl J Med. 2008;359:1577-89.

40. UK Prospective Diabetes Study Group. Tight blood pressure control and risk of macrovascular and microvascular complications in type 2 diabetes. UKPDS 38. BMJ. 1998;317:703-13.

41. ACCORD Study Group, Cushman WC, Evans GW, Byington RP, Goff DC Jr, Jr GrimmRH, Cutler JA, Simons-Morton DG, Basile JN, Corson MA, Probstfield JL, Katz L, Peterson KA, Friedewald WT, Buse JB, Bigger JT, Gerstein HC, Ismail-Beigi F. Effects of intensive blood-pressure control in type 2 diabetes mellitus. $\mathrm{N}$ Engl J Med. 2010;362:1575-85.

42. Shimamoto K, Ando K, Fujita T, Hasebe N, Higaki J, Horiuchi M, Imai Y, Imaizumi T, Ishimitsu T, Ito M, Ito S, Itoh $\mathrm{H}$, Iwao $\mathrm{H}$, Kai H, Kario K, Kashihara N, Kawano Y, Kim-Mitsuyama S, Kimura G, Kohara K, Komuro I, Kumagai H, Matsuura H, Miura K, Morishita R, Naruse M, Node K, Ohya Y, Rakugi H, Saito I, Saitoh S, Shimada K, Shimosawa T, Suzuki H, Tamura K, Tanahashi N, Tsuchihashi T, Uchiyama M, Ueda S, Umemura S. The Japanese Society of Hypertension Guidelines for the Management of Hypertension (JSH 2014). Hypertens Res. 2014;37:253-390.

43. Ohsawa M, Itai K, Tanno K, Onoda T, Ogawa A, Nakamura M, Kuribayashi T, Yoshida Y, Kawamura K, Sasaki S, Sakata K, Okayama A. Cardiovascular risk factors in the Japanese northeastern rural population. Int J Cardiol. 2009;137:226-35.

44. Omama S, Yoshida Y, Ogasawara K, Ogawa A, Ishibashi Y, Ohsawa M, Tanno K, Onoda T, Itai K, Sakata K, Okayama A. Incidence rate of cerebrovascular diseases in northern Japan determined from the Iwate Stroke Registry with an inventory survey system. J Stroke Cerebrovasc Dis. 2013;22:e317-322.

45. American Diabetes Association. Glycemic targets. Diabetes Care. 2015;38(Suppl):S33-40. 